\title{
MENGARTIKULASIKAN "TRIAL BY THE PRESS" DALAM KEMASAN PEMBERITAAN MEDIA YANG BERORIENTASI KEMASLAHATAN
}

\author{
Amir Machmud NS \\ Harian Suara Merdeka \\ Email: amir_machmud@suaramerdeka.com
}

\begin{abstract}
Article 3 (1) of Law No. 40 of 1999 declared that the national press has a function as a social control. But this function of pers is not optimal yet. This article is intended to determine whether oriented news such as the benefit of law enforcement can be understood not as a violation of the journalistic principle of trial by the press and the impetus to create an atmosphere of anti-corruption whether they can be formulated in the packaging articulate the contribution of the media. The conclusion are the reporting must emphasizes covers all sides with regard to the principles of journalism, Pers must to create an atmosphere of anti-corruption through progressive choices with the principle of trial by the press and the discipline of verification.
\end{abstract}

Keywords: Trial by The Press; Pers; Benefits.

\begin{abstract}
Abstrak
Pasal 3 ayat (1) UU No. 40 Tahun 1999 menyatakan salah satu fungsi pers nasional adalah kontrol sosial. Namun fungsi kontrol pers dinilai masih kurang. Artikel ini bermaksud mengetahui pemberitaan seperti apakah yang berorientasi kemaslahatan penegakan hukum dapat dipahami bukan sebagai pelanggaran prinsip jurnalistik trial by the press dan daya dorong untuk menciptakan atmosfer anti-KKN seperti apakah yang bisa diformulasikan dalam kemasan artikulatif kontribusi media. Kesimpulannya pemberitaan yang berorientasi kemaslahatan penegakan hukum adalah pemberitaan yang menekankan pada covers all sides dengan memperhatikan asas dan prinsip-prinsip jurnalisme. Daya dorong untuk menciptakan atmosfer anti-KKN berupa pemberdayaan langkah progresif dengan kepatuhan terhadap asas trial by the press dan disiplin verifikasi.
\end{abstract}

Kata Kunci: Trial by The Press; Media; Kemaslahatan.

\section{A. Pendahuluan}

Kebebasan pers telah menjamin pelaksanaan fungsi kontrol media sejak era reformasi (1998) dibandingkan dengan praktik kehidupan pers ketika masa rezim Orde Baru. Dalam era reformasi pers memiliki kedudukan sangat terhormat karena institusi ini berfungsi sebagai the fourth estate (pilar kekuasaan keempat). ${ }^{1}$ Hal itu ditandai dengan lahirnya UU No. 40 Tahun 1999 tentang Pers yang telah mendorong kesadaran baru tentang terbukanya ruang untuk melaksanakan fungsi kontrol sosial publik secara lebih kuat dan terarah.

Pasal 3 ayat (1) UU No. 40 Tahun 1999 menyatakan pers nasional mempunyai fungsi sebagai media informasi, pendidikan, hiburan, dan kontrol sosial. Hikmat Kusumaningrat dan Purnama Kusumaningrat menjelaskan bahwa fungsi kontrol pers yang dimaksud adalah fungsi kontrol yang bertanggung jawab dimana pers masuk ke balik panggung kejadian untuk menyelidiki pekerjaan pemerintah atau perusahaan. ${ }^{2}$ Pers harus memberitakan apa yang berjalan baik dan tidak berjalan baik. Fungsi "watchdog"

\footnotetext{
1. Tjipta Lesmana, "Kebebasan Pers Dilihat dari Perspektif Konflik, antara Kebebasan dan Tertib Sosial”, Jurnal Ilmu Komunikasi, Vol.2, No.1, Juni 2005, 1-14, hlm 5.

2. Hikmat Kusumaningrat \& Purnama Kusumaningrat, 2009, Jurnalistik Teori dan Praktik, Bandung, PT Remaja Rosdakarya, hlm 27.
} 
atau fungsi kontrol ini harus dilakukan secara lebih aktif oleh pers daripada oleh kelompok masyarakat lainnya. Melalui fungsi kontrol sosial, media mengartikulasikan peran publik dalam kebebasan menyampaikan pendapat untuk mengawal penyelenggaraan negara dan pemerintahan yang transparan dan akuntabel. Sebagaimana dinyatakan dalam Penjelasan Umum UU No. 40 Tahun 1999 bahwa pers melaksanakan kontrol sosial sangat penting untuk mencegah terjadinya penyalahgunaan kekuasaan baik korupsi, kolusi, nepotisme, maupun penyelewengan dan penyimpangan lainnya. Hinca IP Pandjaitan dan Amir Effendi Siregar menyatakan dalam menjalankan fungsi kontrol sosial, pers memberikan peringatan dini atas kemungkinan terjadinya penyalahgunaan kekuasaan, sehingga penyalahgunaan kekuasaan itu tidak atau jangan sampai terjadi. $^{3}$

Namun demikian dalam kenyataannya, sisi ideal tentang peran media untuk menjalankan fungsi kontrol, dianggap belum mampu menciptakan atmosfer yang kuat sebagai sikap bersama anti-KKN. Belum ada efek jera yang bisa diciptakan oleh prosesproses hukum dari berbagai kasus yang ada. Maka dari itu dalam orientasi kebijakan pemberitaan untuk membangun efek jera, sesungguhnya dibutuhkan sebuah kekuatan yang mampu menerbitkan pikiran untuk mengubah perilaku. Target pembaca pemberitaan itu ditujukan bukan hanya para pelaku yang tengah menjalani proses hukum, melainkan juga yang lebih penting adalah para calon pelaku atau publik secara umum. Persoalannya apakah prinsip-prinsip dalam pekerjaan jurnalistik, terutama kode etik kewartawanan, memberi cukup ruang bagi dorongan kekuatan efek determinatif itu, sehingga menambah daya dalam menciptakan pengaruh bagi para pelaku korupsi dan terutama untuk membangun atmosfer takut melakukan kejahatan itu. Artinya, selain pemberitaan diharapkan ikut menciptakan rasa malu lewat eksposeekspose yang masif, juga berisi berbagai sisi proses penegakan hukum, termasuk akibat- akibat dan dampak sosialnya apabila seseorang terlibat kasus korupsi.

Persoalan yang sering menghadang dalam ikhtiar membangun totalitas keberpihakan kepada kepentingan publik dalam penyajian berita-berita penegakan hukum, sebagian justru muncul dari penafsiran kaku terhadap prinsip dan asasasas jurnalistik sendiri. Prinsip-prinsip itu telah dituangkan sebagai pedoman penulisan bidang hukum, misalnya asas presumption of innocence, equality before the law, dan larangan terjadinya trial by the press. Secara etis, pers terikat dengan prinsip-prinsip yang menjadi jiwa dalam kode etik profesi kewartawanan sehingga dalam menjalankan profesinya selalu bekerja dengan cermat. Penghayatan etika dan kecermatan sikap dalam memberitakan kasus-kasus hukum, termasuk penegakan hukum masalah korupsi, akan mencegah kemungkinan wartawan melakukan pelanggaran.

Apabila dipahami bahwa tujuan ideal berjurnalistik adalah mencapai kemaslahatan hidup bersama, maka fungsi kontrol sosial media mestinya juga diorientasikan untuk menuju ke budaya tatanan penyelenggaraan kehidupan berbangsa dan bernegara, serta pemerintahan yang transparan dan akuntabel. Muara ideal itu tentulah diharapkan menjadi spirit penghela tercapainya kesejahteraan lahir-batin rakyat, baik secara ekonomi maupun dalam memperoleh rasa keadilan. Namun demikian disadari bahwa atmosfer efek jera belum bisa sepenuhnya diciptakan oleh pengaruh pemberitaan penegakan hukum masalah korupsi, terbukti dari masih merajalelanya kejahatan luar biasa itu dari waktu ke waktu.

Memperhatikan pentingnya kekuatan determinasi media dalam pemberitaan yang memberi kontribusi untuk menciptakan efek jera, dengan tetap memperhatikan penghayatan prinsip-prinsip jurnalistik, etika kewartawanan, dan berbagai aturan dalam proses penegakan hukum maka penting untuk dikaji tentang seperti apakah pemberitaan yang berorientasi kemaslahatan penegakan hukum dapat dipahami bukan sebagai

\footnotetext{
3. Hinca IP Pandjaitan \& Amir Effendi Siregar, 2004, 1001 Alasan Undang-Undang Pers Lex Specialis, Jakarta, Badan Bantuan Hukum dan Advokasi Kemerdekaan Pers SPS, hlm 5-6.

4. Amir Machmud NS,"Komunikasi Efek Jera”, Suara Merdeka, 6 April 2016, hlm 4.
} 
pelanggaran prinsip jurnalistik trial by the press. Kemudian melalui kesadaran bahwa korupsi merupakan kejahatan luar biasa, maka seperti apakah daya dorong untuk menciptakan atmosfer anti-KKN yang bisa diformulasikan dalam kemasan artikulatif kontribusi media.

\section{B. Pembahasan \\ 1. Prinsip Trial By The Press}

Profesionalisme wartawan dan media merupakan kunci utama bagi kehidupan pers yang sehat. Fungsi media yang diamanatkan oleh UU No.40 Tahun 1999 akan berjalan dengan baik apabila profesionalisme dihayati sebagai sikap yang bisa melindungi tugas profesi wartawan, kehidupan media, dan masyarakat. Melalui profesionalisme, pers menjamin diri untuk meraih kepercayaan publik dan kemartabatannya. Sikap profesional itu bisa dirumuskan sebagai pemenuhan syarat kecakapan teknis (skill) kewartawanan sekaligus kemampuan untuk mengeksplorasi kearifan etis. Seorang wartawan yang cakap secara teknis, belum cukup untuk disebut sebagai jurnalis yang profesional apabila tidak menghayati kode etik profesinya. Menghayati berarti mengalirkan pemahaman kode etik itu ke dalam keseharian tugas-tugas profesinya, sehingga memancar dalam perilaku kewartawanannya.

Trial by the press atau terjemahannya secara harfiah "pengadilan oleh pers" sebagaimana dikutip dalam laporan penelitian hukum BPHN tahun 2013 merupakan kegiatan dimana pers bertindak sebagai peradilan mencari bukti-bukti, menganalisa, dan mengkaji sendiri untuk kemudian berakhir dengan memberi putusan. Secara teori, pers dianggap telah melakukan trial by the press ketika dengan adanya pemberitaan mengenai sebuah dugaan kasus pidana yang sudah ditangani aparat penyidik (pre-trial publicity) hingga masuk ke pengadilan (publicity during trial) menyebabkan adanya pihak yang tertuduh dan dipojokkan pada posisi yang sulit untuk memperoleh peradilan yang bebas dan tak berpihak (fair trial). ${ }^{6}$ Senada dengan pengertian tersebut, Janet Steele sebagaimana dikutip dari (Bruschke \& Loges 2004; Kando 1990; Landau 1976; Stabile 1990), menulis trial by the press biasanya digunakan dalam konteks pre-trial publicity dan Amandemen pertama mengenai hak kebebasan berekspresi versus Amandemen keenam tentang hak-hak tersangka untuk mendapatkan peradilan yang adil dan tidak memihak. Sebagaimana dinyatakan: "In the United States, when journalists, social scientists, or legal scholars use the term "trial by the press," it is usually in the context of pretrial publicity, and the First Amendment right to freedom of expression versus the Sixth Amendment right of the accused to a fair trial." 7

Trial by the press jelas merupakan praktik jurnalistik yang melanggar baik ketentuan yang diatur oleh Pasal 7 Kode Etik Jurnalistik maupun Pasal 4 Ayat (3) dan Pasal 8 UU No. 14 Tahun 1970. Pasal 7 Kode Etik Jurnalistik berbunyi: "Wartawan dalam memberitakan peristiwa yang diduga menyangkut pelanggaran hukum dan atau proses peradilan harus menghormati asas praduga tak bersalah, prinsip adil, jujur, dan penyajian yang berimbang". Selanjutnya Pasal 4 ayat (3) UU No. 14 Tahun 1970 menegaskan bahwa: "Segala campur tangan dalam urusan peradilan oleh pihak-pihak di luar kekuasaan kehakiman dilarang, kecuali dalam hal-hal yang disebut dalam UndangUndang Dasar". Pasal 8 menyatakan bahwa setiap orang yang disangka, ditangkap, ditahan, dituntut, dan/ atau dihadapkan di depan pengadilan, wajib dianggap tidak bersalah sebelum adanya putusan pengadilan yang menyatakan kesalahannya dan memperoleh kekuatan hukum yang tetap.

Mengenai trial by the press ini, Persatuan Wartawan Indonesia (PWI) juga memberikan pedoman yang rinci dalam "Sepuluh Pedoman Penulisan tentang Hukum". Pedoman keenam antara lain

5.Ni Putu Noni Suharyanti, "Perspektif HAM Mengenai Penerapan Asas Praduga Tidak Bersalah Dalam Kaitannya Dengan Pemberitaan Di Media Massa”, Jurnal Advokasi,Vol. 5, No.2, September 2015, 123-128, hlm 126.

6.BPHN Kementerian Hukum dan HAM RI, "Pengaruh Praktik Courtroom Television Terhadap Independensi Peradilan", Penelitian Hukum, BPHN Kementerian Hukum dan HAM RI, 2013, hlm 30.

7.Janet Steele, "Trial by the Press": An Examination of Journalism, Ethics, and Islam in Indonesia and Malaysia", The International Journal of Press/Politics, 18(3) 342-359, p.342-343. 
menyebutkan bahwa untuk menghindarkan trial by the press, pers hendaknya memperhatikan sikap terhadap hukum dan sikap terhadap tertuduh. Jadi hukum atau proses pengadilan harus berjalan dengan wajar. Tertuduh jangan sampai dirugikan posisinya berhadapan dengan penuntut umum. Juga perlu diperhatikan supaya tertuduh kelak bisa kembali dengan wajar ke dalam masyarakat. Dalam pedoman ketujuh ditekankan secara teknis bahwa untuk menghindari trial by the press, nada dan gaya tulisan atau berita jangan sampai ikut menuduh, jangan membayangkan bahwa tertuduh adalah orang jahat, dan jangan menggunakan kata-kata yang bersifat opini. Misalnya memberitakan bahwa "saksi-saksi memberatkan terdakwa" atau "tertuduh memberikan keterangan yang berbelit-belit". Kemudian pedoman kedelapan menambahkan tentang cover all sides secara wajar, serasi, dan seimbang (tidak berat sebelah). Media harus memberi tempat dalam pemberitaan secara wajar bagi semua pihak yang ikut berpartisipasi dalam suatu proses pemeriksaan perkara di depan meja hijau.

Berkaitan dengan hal itu, kode etik jurnalistik wartawan Indonesia menekankan pentingnya relasi yang bersifat menjaga tanggung jawab sosial bersama antara pers dengan publik. Wartawan, bersama seluruh masyarakat wajib mewujudkan prinsipprinsip kemerdekaan pers yang profesional dan bermartabat. Tugas dan tanggung jawab yang luhur itu hanya dapat dilaksanakan, apabila wartawan selalu berpegang teguh kepada kode etik jurnalistik dan masyarakat memberi kepercayaan penuh serta menghargai integritas profesi tersebut. Kemartabatan seorang wartawan antara lain akan diukur dari sejauh mana kemauannya untuk memahami, menghayati, dan melaksanakan kode etik profesinya. Penilaian dan kepercayaan publik bakal bergantung pada kemanfatan yang dirasakan dari kinerja wartawan yang profesional.

Dalam mencari, mengolah, dan menulis berita, idealnya penghayatan etik itu selalu menjadi penuntun yang mewarnai sikap dan perilaku seorang wartawan. Selanjutnya di ruang pemberitaan atau newsroom, pilihanpilihan etik itu akan terolah melalui keputusan tentang arah kebijakan redaksional. Keputusan tentang kebijakan pemberitaan akan menjadi gambaran media tersebut dalam memilih sikap atas sebuah isu publik atau peristiwa tertentu.

\section{Realitas Tuntutan Peran Media}

Tak bisa dipungkiri, masyarakat menuntut media sebagai representasi kemerdekaan berpendapat, mewujudkan hakhak publik untuk memperoleh informasi, hak untuk memperoleh pendidikan, hak untuk memperoleh hiburan, dan hak untuk melaksanakan kontrol sosial. Di dalamnya terkandung hak berpartisipasi dalam mengawasi kekuasaan, termasuk mengawal proses-proses penegakan hukum. Maka untuk menjamin terpenuhinya hak-hak publik itu, walaupun di era reformasi ini pemerintah (kekuasaan) tidak lagi mengintervensi penyelenggaraan media massa seperti pada masa orde baru, namun kehidupan media tetaplah diatur melalui perangkat hukum.

Ada dua sisi kepentingan dalam pengaturan bidang media, yaitu: pertama, pertimbangan kepentingan umum atau kepentingan publik. Atas nama kepentingan umum atau kepentingan masyarakat, negara harus mengatur dalam konstitusinya mengenai Hak Asasi Manusia (HAM). Salah satu unsur HAM adalah hak menyatakan pendapat. Salah satu cara menyatakan pendapat di muka umum adalah dengan menggunakan media massa. Oleh karena itu, media pada dasarnya adalah alat bagi masyarakat luas untuk menyatakan pendapatnya secara bebas. ${ }^{8}$ Dari sisi ini, media harus dilindungi dari segala bentuk pengekangan atau gangguan lainnya, agar rakyat tidak terganggu dalam menyatakan pendapatnya. Terganggunya keberadaan media akan merupakan gangguan bagi rakyat untuk menyatakan pendapat. Terhambatnya rakyat untuk menyampaikan pendapat berarti terhambatnya pelaksanaan HAM. Melemahnya pelaksanaan HAM sama dengan melemahnya penegakan konstitusi. ${ }^{9}$

Kedua, kepentingan bisnis. Pada sisi lain, telah menjadi kenyataan bahwa

8. Hari Wiryawan, 2007, Dasar-Dasar Hukum Media, Yogyakarta, Pustaka Pelajar, hlm 133-134.
9. Ibid. 
pengelolaan media dilakukan oleh sebuah organisasi yang pada umumnya untuk mencari laba (business oriented) dalam sistem ekonomi kapitalis. Mengingat hal itu maka jiwa "kepentingan umum" pada media bisa terkontaminasi oleh kepentingan privat perusahaan. Dari sisi ini media harus dikendalikan agar tidak merugikan masyarakat. Pengalaman praktik media yang berpihak kepada kepentingan-kepentingan tertentu, baik sosial, politik, ekonomi, maupun hukum bagaimanapun telah dirasakan sebagai luka yang mencederai tujuan mulia berjurnalistik, karena independensi tidak lagi dimahkotakan sebagai prinsip etis.Maka, tuntutan agar media mengorientasikan kebijakan pemberitaannya untuk sebesar-besarnya tujuan kemaslahatan masyarakat tentu membutuhkan pendekatan-pendekatan sikap, kebijakan, hingga segi-segi yang bersifat teknis, termasuk ketika harus bersikap untuk memberi kontribusi dalam membangun atmosfer penegakan hukum melawan korupsi.

Dari paparan tersebut, maka pengejawantahan etika jurnalistik dalam pemberitaan yang bersifat kontrol sosial membutuhkan formulasi pemberitaan yang mendorong pencerdasan masyarakat untuk membangun kultur antikorupsi, dan lebih jauh lagi mampu menciptakan atmosfer efek jera.

\section{Opini Publik dan Opini Hukum}

Salah satu yang dikembangkan dari teori-teori ilmu komunikasi dalam praktik kehidupan media utuk mewujudkan tujuan berjurnalistik adalah model-model pemberitaan yang mampu mempengaruhi pendapat umum. Secara alamiah, pemberitaan media massa memang punya kemampuan untuk mempengaruhi opini publik, baik negatif maupun positif. Kebijakan tampilan pemberitaan itu akan memberi pengaruh lebih kuat apabila dilakukan dengan cara, arah, dan tujuan yang lebih sistematis. Pengertian dari opini publik itu sendiri adalah pendapat sekelompok masyarakat atau sintesis dari pendapat seseorang dan diperoleh dari suatu diskusi publik dari pihak-pihak yang memiliki kaitan kepentingan. Agregat dari sikap dan kepercayaan ini biasanya dianut oleh populasi orang dewasa. Dalam menentukan opini publik, yang dihitung bukanlah jumlah mayoritasnya (numerical majority) namun mayoritas yang efektif (effective majority). ${ }^{10}$

Kenyataannya media massa berpondasi pada bahasa, kekuatan kata-kata dan kalimat. Alex Sobur dengan mengutip Ana Nadya Abrar dari pendapat Paul Watson, salah seorang pendiri Greenpeace menyatakan bahwa konsep kebenaran yang dianut oleh media massa bukanlah kebenaran sejati, tetapi sesuatu yang dianggap masyarakat sebagai kebenaran. Ringkasnya, kebenaran ditentukan oleh media massa. Jika sinyalemen ini benar, dapat dibayangkan betapa beratnya pembaca dalam menyikapi sebuah berita. Pembaca harus memiliki kemampuan memadai untuk menyaring sebuah berita agar menemukan kebenaran," setidak-tidaknya mendekati kebenaran. Selanjutnya Sobur menambahkan, isi media pada hakikatnya adalah hasil konstruksi realitas dengan bahasa sebagai perangkat dasarnya. Sedangkan bahasa bukan saja sebagai alat merepresentasikan realitas, namun juga bisa menentukan relief seperti apa yang akan diciptakan oleh bahasa tentang realitas tersebut. Akibatnya, media massa mempunyai peluang yang sangat besar untuk mempengaruhi makna dan gambaran yang dihasilkan dari realitas yang dikonstruksikannya. ${ }^{12}$

Pendapat umum atau opini publik tentu dibangun untuk bermacam-macam kepentingan, namun dalam orientasi kemaslahatan melalui sebuah agenda setting tertentu di newsroom, melalui upaya pemancaran etika, akan bisa didapat model etis pemberitaan yang beraksentuasi pada kepentingan orang banyak. Berkaitan dengan pentingnya posisi pendapat umum itu dalam hukum, Satjipto Rahardjo menjelaskan bahwa sekalipun orang menerima peranan dari pendapat umum dalam hukum, namun orang tersebut tidak selalu hadir secara

\footnotetext{
10. "Opini Publik", tersedia di website http//generasi-rabbani-madani.blogspot.co.id, diakses pada tanggal 15 Juli 2015.

11. Alex Sobur, 2006, Analisis Teks Media, Bandung, PT Remaja Rosdakarya, hlm 87.

12. Ibid, hlm 88 .
} 
absolut sebagai suatu pendapat yang dihayati oleh umum. Terkadang, orang itu hanya diwakili oleh individu yang kuat dalam masyarakat yang kemudian mampu memasukkan kehendaknya (baca: pendapatnya) ke dalam hukum dengan dalih mewakili pendapat orang banyak. Kondisi itu tidak bisa dikontrol apakah pendapat tersebut memang mewakili pendapat umum ataukah tidak. Satu orang atau sekelompok kecil orang-orang, yang lazim disebut sebagai golongan elite tersebut. Bisa saja pendapat tersebut tidak mengacu kepada pendapat rakyat yang sesungguhnya, melainkan kepada sumber-sumber lain tertentu. ${ }^{13}$

Atas dasar hal itu maka dibutuhkan sikap kewartawanan yang memahkotakan penghayatan disiplin verifikasi. Prinsip cover all sides merupakan sikap yang tidak bisa ditawar-tawar, sehingga sebuah pemberitaan hukum tidak lahir hanya dari pernyataan atau opini seseorang atau sekelompok orang, namun didukung oleh fakta-fakta yang telah dengan cermat diverifikasi. Tuntutan kecepatan untuk mengejar aktualitas, termasuk untuk meng-up date berita yang bersifat running seperti dalam praktik wartawan media-media online, tidak boleh mengabaikan kewajiban check and recheck dan tetap harus meliput dari banyak sisi. Untuk memberikan bobot tekan pemberitaan yang bernilai kemaslahatan, bekal ketercukupan verifikasi merupakan syarat terpenting.

Berkaitan dengan hal itu, Kovach dan Rosenstiel menegaskan pada akhirnya disiplin verifikasi adalah ihwal yang memisahkan jurnalisme dari hiburan, propaganda, fiksi, atau seni. Hiburan (entertainment) dan sepupunya infotainment berfokus pada hal-hal yang paling menggembirakan hati. Propaganda menyeleksi fakta atau mengarang fakta demi kepentingan yang lain, persuasi dan manipulasi. Fiksi mengarang skenario untuk sampai pada kesan yang lebih personal dari apa yang disebut kebenaran. Hanya jurnalisme yang sejak awal berfokus yang bisa menceritakan apa yang terjadi setepat-

\section{tepatnya. ${ }^{14}$}

\section{Realitas Orientasi Kebijakan Media}

Dalam mekanisme produksi berita, menjaga profesionalitas dimulai dari wartawan sebagai ujung tombak, hingga memasuki mekanisme struktur produksi dalam sistem redaksional di dapur redaksi atau yang dikenal sebagai newsroom. Di dalam struktur itu ada redaktur yang berperan menyunting tulisan wartawan, ada redaktur pelaksana sebagai pimpinan produksi berita, hingga pemimpin redaksi sebagai fungsi tertinggi dalam menentukan kebijakan redaksional. Apabila meminjam elemenelemen jurnalisme Bill Kovach dan Tom Rosenstiel, maka pertanyaan tentang mekanisme dalam proses produksi berita ini sangatlah mengusik, yakni kepada siapakah loyalitas pertama jurnalisme harus dipersembahkan. Lebih lanjut ditegaskan bahwa komitmen kepada warga (citizen) lebih besar ketimbang egoisme profesional. Tersirat di dalamnya perjanjian dengan publik, yang menyatakan kepada pembaca bahwa ulasan filmnya jujur, bahwa ulasan restorannya tak dipengaruhi oleh pemasang iklan, dan liputannya tidak untuk kepentingan pribadi atau condong untuk kepentingan teman-teman. Kesetiaan kepada warga, menurut keduanya, adalah makna dari yang kita sebut independensi jurnalistik. ${ }^{15}$

Loyalitas, komitmen, a tau keberpihakan sebagai elemen dalam jurnalisme merupakan sikap yang akan dipilih atau tidak dipilih oleh suatu media. Proses pergulatan untuk mengolah, lalu menetapkan pilihan-pilihan sikap itu berlangsung di ruang redaksi atau newsroom. Di sinilah profesionalitas kewartawanan dipertaruhkan, karena pilihan tentang penyajian berita yang meliputi penentuan judul, pengambilan sudut pandang (angle), penempatan berita dalam layout, melengkapi berita tersebut dengan foto-foto atau infografik, hingga arah pemberitaan diputuskan. Agenda setting yang tersirat dari pilihan kebijakan pemberitaan itu adalah: sebuah berita akan disajikan dengan model seperti apa, arahnya ke mana, dimuati pesan

13. Satjipto Rahardjo, 2000, Ilmu Hukum, Bandung, PT Citra Aditya Bakti, hlm 156-157.

14. Bill Kovach \& Tom Rosenstiel, 2004, Elemen-Elemen Jurnalisme, Jakarta, ISAI, hlm 87.

15. Ibid,hlm 59. 
apa, bahkan dengan target apa, menggambarkan agenda setting media tersebut sebagai produk pilihan manajemen redaksional, yang tentu merupakan konstruksi olahan dari berbagai faktor pertimbangan.

Dalam praktik newsroom, termasuk untuk penyiapan berita-berita penegakan hukum, akan berlangsung pergulatan agenda, yakni misalnya penentuan sikap media kita tentang kasus hukum tertentu. Apakah ada kepentingan secara terang-terangan atau terselubung yang melibatkan perusahaan, seperti kepentingan pengambil keputusan di redaksi, orang-orang redaksi, atau wartawannya. Atau mungkin berita tersebut terkait dengan kepentingan jangka pendek, jangka menengah, dan jangka panjang bagian iklan, pemasaran, dan marketing communications. Segi-segi dinamis pengambilan sikap di newsroom inilah yang akan memformulasikan agenda setting media tersebut melalui kebijakan redaksionalnya.

Determinasi pengambilan kebijakan redaksional dilakukan dengan tidak melanggar asas dan prinsip pers tetapi tetap dilakukan secara proporsional, cover all sides, namun dengan penempatan berita yang menonjol untuk mempengaruhi pendapat umum. Akan tetapi, bisa pula dilakukan melalui nuansa dan proses-proses sebaliknya. Determinasi kebijakan bisa diformulasikan untuk arah tertentu mempengaruhi pendapat umum, dan lebih khusus lagi secara langsung maupun tidak langsung mempengaruhi proses hukum yang sedang berlangsung. Maka pekerjaan-pekerjaan penyuntingan berita di dapur redaksi dilakukan sampai pada tahap analisis pembingkaian (framing) untuk menciptakan bentuk-bentuk arah opini mulai dari judul, angle, penempatan berita, bahkan pemilihan narasumber-narasumbernya.

\section{Jurnalisme Maslahat dalam Penegakan Hukum}

Dari analisis-analisis tersebut, pertanyaan tentang orientasi kemaslahatan sebuah produksi berita sesungguhnya dapat dilihat dari sisi negatif sekaligus positif. Dari sisi negatif, tentu terjadi gesekan-gesekan dengan sikap profesional wartawan dan media, sedangkan dari sisi positif, justru akan berlangsung penguatan profesionalitas apabila wartawan, media, dan newroom-nya mampu mengagendakan pemaksimalan tujuan kemaslahatan.

Jurnalisme maslahat sebagai sumbangan dalam dunia penegakan hukum sangatlah terbuka kemungkinannya untuk dikembangkan sebagai model pemberitaan yang secara artikulatif menjauhi pelanggaran asas trial by the press. Melalui arah kebijaksaan redaksional media, pesan-pesan tentang arah kemaslahatan itu dikreasi dengan cara menyampaikan segi-segi progresif pemberitaan yang memberi kekuatan determinatif bagi proses-proses penegakan hukum. Hal ini sesuai dengan pendapat dari Kovach dan Rosenstiel yang menyatakan "Tujuan utama jurnalisme adalah menyampaikan kebenaran sehingga orangorang akan mempunyai informasi yang mereka butuhkan untuk berdaulat". ${ }^{16}$

Berkaitan dengan pelanggaran trial by the press, Fian Faju mengajukan beberapa saran yakni: pertama, sudah saatnya para penegak hukum menggunakan UU No.40 Tahun 1999 dalam menyelesaikan kasuskasus yang terkait dengan kegiatan jurnalistik, dan mengesampingkan KUHP yang menurut catatan sejarah tidak dapat memberikan perlindungan yang aman bagi kemerdekaan pers; Kedua, pelanggaran kode etik jurnalistik harus diselesaikan dengan mekanisme jurnalistik, bukan dengan mekanisme konvensional melalui pengadilan; Ketiga, peradilan tidak perlu lagi melihat pers sebagai "penyusup" yang mencampuri urusan internal peradilan, tetapi sebagai mitra yang dapat mendekatkan peradilan dengan publik pencari keadilan; Keempat, pers perlu terus mengevaluasi diri untuk meningkatkan profesionalismenya dan membuka diri terhadap kontrol publik, sehingga dapat menjadi media yang membangun peradaban publik yang lebih baik. $^{17}$

\footnotetext{
16. Kovach \& Rosenstie, Op.cit, hlm 15.

17. Fian Paju, "Trial by The Pers di Indonesia", tersedia di website http://www.kompasiana.com/fianpaju/trialby-the-press-di-indonesia, 09 Februari 2012 diakses pada tanggal 20 Juni 2015.
} 


\section{Simpulan}

Berdasarkan uraian di atas dapat disimpulkan bahwa pemberitaan yang berorientasi kemaslahatan penegakan hukum dapat dipahami bukan sebagai pelanggaran prinsip jurnalistik trial by the press adalah pemberitaan yang lebih menekankan pada covers all sides dengan memperhatikan asas dan prinsip-prinsip jurnalisme. Daya dorong untuk menciptakan atmosfer anti-KKN yang bisa diformulasikan dalam kemasan artikulatif kontribusi media adalah memberdayakan langkah progresif mengenai pilihan-pilihan model pemberitaan dengan mengartikulasikan kepatuhan terhadap asas trial by the press. Upaya tersebut dilakukan dengan tanpa mengesampingkan disiplin verifikasi yang menjadi bekal profesionalitas seorang wartawan. Profesionalisme wartawan harus dipahami secara komprehensif, yakni mempunyai bekal kompetensi berupa kecakapan teknis (skill) dan kemauan untuk mengeksplorasi kearifan etik. Melalui kombinasi dua hal ini, wartawan punya kesigapan nurani untuk memutuskan formulasi pemberitaan yang berorientasi kemaslahatan bersama.

\section{Daftar Pustaka}

BPHN Kementerian Hukum dan HAM RI, "Pengaruh Praktik Courtroom Television Terhadap Independensi Peradilan", Penelitian Hukum, BPHN Kementerian Hukum dan HAM RI, 2013.

Kovach Bill \& Tom Rosenstiel, 2004, Elemen-Elemen Jurnalisme, Jakarta, ISAI.

Kusumaningrat Hikmat \& Purnama Kusumaningrat, 2009, Jurnalistik Teori dan Praktik, Bandung, PT Remaja Rosdakarya.

Lesmana Tjipta, "Kebebasan Pers Dilihat dari Perspektif Konflik, antara Kebebasan dan Tertib Sosial", Jurnal Ilmu Komunikasi, Vol.2, No.1, Juni 2005.

Machmud NS Amir,'Komunikasi Efek Jera", Suara Merdeka, 6 April 2016.

Noni Suharyanti Ni Putu, "Perspektif HAM Mengenai Penerapan Asas Praduga Tidak Bersalah Dalam Kaitannya
Dengan Pemberitaan Di Media Massa", Jurnal Advokasi,Vol. 5, No.2, September 2015, 123-128.

Paju Fian, "Trial by The Pers di Indonesia", tersedia di website http://www. kompasiana.com/fianpaju/trial-by-thepress-di-indonesia, 09 Februari 2012 diakses pada tanggal 20 Juni 2015.

Pandjaitan Hinca IP \& Amir Effendi Siregar, 2004, 1001 Alasan Undang-Undang Pers Lex Specialis, Jakarta, Badan Bantuan Hukum dan Advokasi Kemerdekaan Pers SPS.

Rahardjo Satjipto, 2000, Ilmu Hukum, Bandung, PT Citra Aditya Bakti.

Sobur Alex, 2006, Analisis Teks Media, Bandung, PT Remaja Rosdakarya.

Steele Janet, "Trial by the Press": An Examination of Journalism, Ethics, and Islam in Indonesia and Malaysia", The International Journal of Press/Politics, 18(3) 342-359, p.342-343.

Wiryawan Hari, 2007, Dasar-Dasar Hukum Media, Yogyakarta, Pustaka Pelajar.

"Opini Publik", tersedia di website h t t p / / g e n e r a s i - r a b b a n i madani.blogspot.co.id, diakses pada tanggal 15 Juli 2015. 